\title{
Mobilisation of heavy metals into the urine by CaEDTA: relation to erythrocyte and plasma concentrations and exposure indicators
}

\author{
S ARAKI, H AONO, K MURATA \\ From the Department of Public Health and Hygiene, Medical College of Oita, Hazama-machi, Oita 879-56, \\ Japan
}

ABSTRACT To investigate the effects of calcium disodium ethylenediamine tetra-acetate (CaEDTA) on the urinary excretion, erythrocyte, and plasma concentrations and exposure indicators of seven ${ }_{0}^{\omega}$ heavy metals, CaEDTA was administered by intravenous infusion to 20 workers exposed to lead, zinc, and copper. The workers' blood lead concentrations ranged from 22 to $59 \mu \mathrm{g} / \mathrm{dl}$ (mean $38 \mu \mathrm{g} / \mathrm{dl} \circlearrowleft$

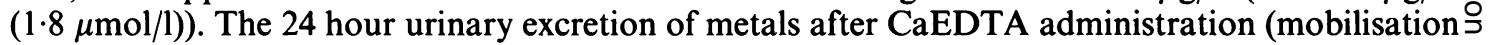
yield) was on average 13 times the background excretion for lead, 11 times for zinc, 3.8 times for $\vec{\oplus}$ manganese, 3.4 times for cadmium, 1.3 times for copper, and 1.1 times for chromium; no significant $\$$ increase was found for mercury. The mobilisation yield of lead $(\mathrm{MPb})$ was significantly correlated $\underset{\mathbb{D}}{\mathrm{D}}$ with whole blood and erythrocyte concentrations and the urinary excretion of lead but not with its $\frac{3}{\sigma}$ plasma concentration; similarly, the mobilisation yield of cadmium was significantly correlated with $\stackrel{\oplus}{-}$ its erythrocyte concentration. In addition, $\mathrm{MPb}$ was significantly correlated with intra-erythrocytic $\vec{\varphi}$ enzyme $\delta$-aminolaevulinic acid dehydratase activity and urinary coproporphyrin excretion. T relation between the mobilisation yield of heavy metals and their body burden (and toxic signs) Is discussed in the light of these findings.

It has recently been shown that plasma lead $(\mathrm{PPb})$ concentration and urinary lead excretion are increased after the intravenous infusion of calcium disodium ethylenediamine tetra-acetate (CaEDTA) without a significant alteration in the lead concentration in either erythrocytes $(\mathrm{EPb})$ or whole blood $(\mathrm{BPb}){ }^{1}{ }^{1}$ This finding suggests that urinary lead is mobilised for the most part from organs other than peripheral blood. The $\mathrm{BPb}$ concentration, on the other hand, is associated closely with the mobilisation yield of lead in urine by CaEDTA (MPb) in workers exposed to lead, ${ }^{2-5}$ indicating that $\mathrm{BPb}$ directly reflects the body burden of chelatable lead. As more than $90 \%$ of $\mathrm{BPb}$ exists in the erythrocytes, the $\mathrm{EPb}$ may also provide a better reflection of the lead body burden (as estimated by $\mathrm{MPb})^{6}$ than the $\mathrm{PPb}$.

The behaviour of zinc in plasma and erythrocytes (PZn and EZn) after CaEDTA infusion was entirely

Accepted 16 January 1986 different from that of lead; the PZn concentration fell $\overrightarrow{\vec{B}}$ rapidly, followed by a gradual rise in the EZn concen- 3 tration during the first five hours after the infusion? had begun. ${ }^{17}$ This observation suggests that chelat-o. able zinc is mobilised mainly from the plasma into the urine shortly after CaEDTA infusion. The depleted $\mathbb{B}$ $\mathrm{PZn}$, however, was mostly compensated for by $\mathrm{a}_{-}^{-}$ redistribution of zinc from other organs during a 243 . hour period. ${ }^{1}$ It must be pointed out that the bodyo burden of chelatable zinc is extremely large and only3 $0.1 \%$ of the body burden is excreted in the urine by CaEDTA per day. ${ }^{8}$ Our previous study has also shown that copper is mobilised into urine without a change in its concentration in either plasma $(\mathrm{PCu})$ or erythrocytes (ECu) after CaEDTA infusion. ${ }^{7}$ o

In the present study we administered CaEDTA intravenously to workers exposed to lead, zinc, and copper; measured the mobilisation yields of these $\omega$ metals as well as four other toxic and essential heavy< metals; and estimated their relation to erythrocyte and plasma concentrations and exposure indicators. 
Mobilisation of heavy metals into the urine by CaEDTA
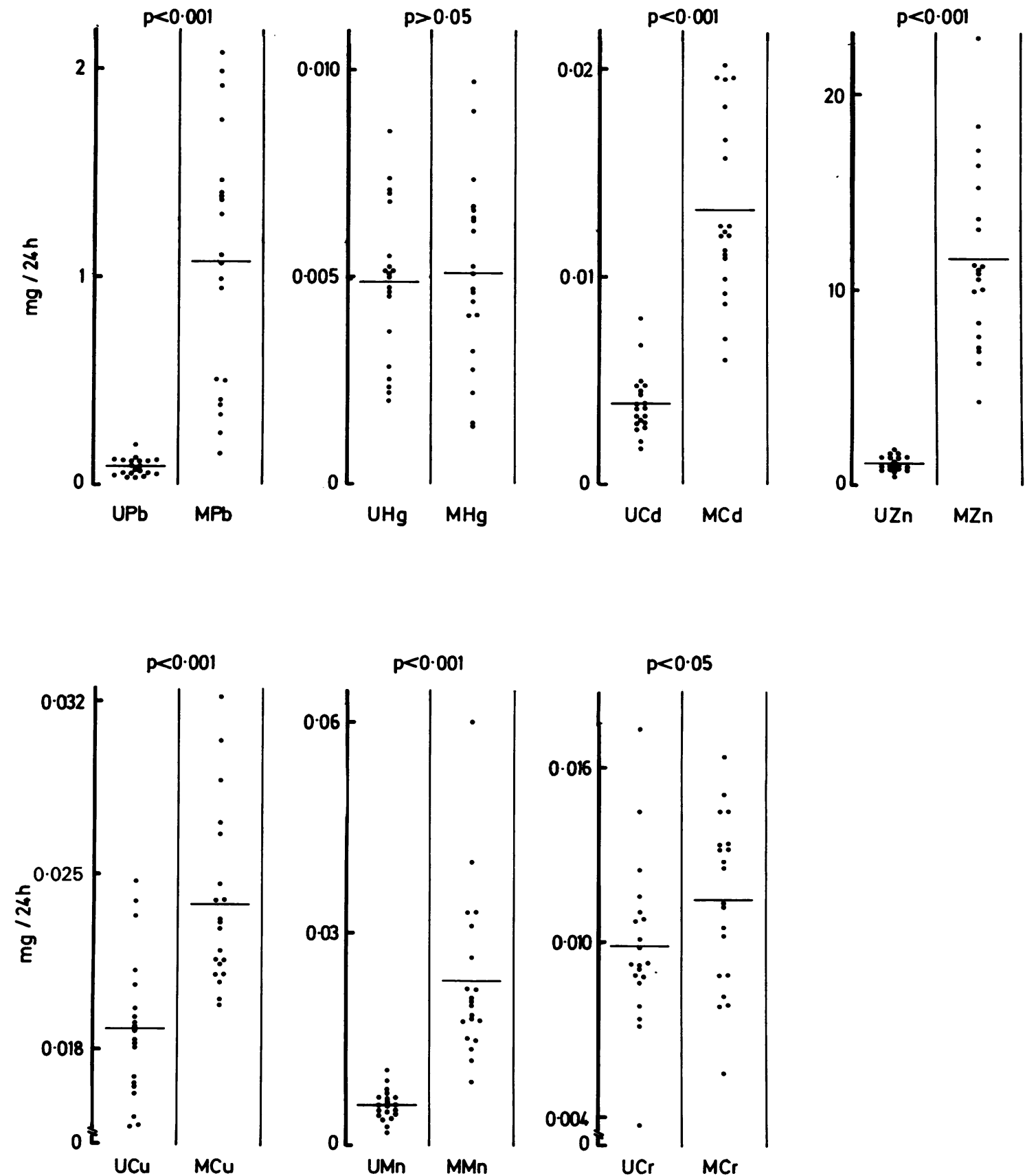

Fig 1 Spontaneous urinary excretion of lead, mercury (total mercury), cadmium, zinc, copper, manganese, and chromium $(\mathrm{UPb}, \mathrm{UHg}, \mathrm{UCd}, \mathrm{UZn}, \mathrm{UCu}, \mathrm{UMn}$, and $U \mathrm{Cr}$ ) and their mobilisation yield in urine by $\mathrm{CaEDTA}(\mathrm{MPb}, \mathrm{MHg}, \mathrm{MCd}, \mathrm{MZn}$, $M C u, M M n$, and $M C r$ ) in 20 subjects. Transverse line in each column shows mean value. In addition, no significant difference was found between urinary excretion of inorganic mercury before and after CaEDTA infusion $(p>0.05) .1 \mathrm{mg} / 24 \mathrm{~h}$ for lead, mercury, cadmium, zinc, copper, manganese, and chromium correspond to 4.8, 5.0,8.9, 15, 16, 18, and $19 \mu \mathrm{mol} / 24 \mathrm{~h}$, respectively. 
Plasma and erythrocyte concentrations of heavy metals in 20 subjects (means with ranges in parentheses)*

\begin{tabular}{|c|c|c|}
\hline & $\begin{array}{l}\text { Plasma } \\
\text { concentration } \\
(\mu g / d l)\end{array}$ & $\begin{array}{l}\text { Erythrocyte } \\
\text { concentration } \\
(\mu g / d l)\end{array}$ \\
\hline $\begin{array}{l}\text { Lead } † \\
\text { Mercury } \ddagger \\
\text { Cadmium } \\
\text { Zinc } \\
\text { Copper } \\
\text { Manganese } \\
\text { Chromium }\end{array}$ & $\begin{array}{l}0.67(0.30-1.00) \\
0.32(0.15-0.77) \\
0.07(0.01-0.18) \\
89(77-111) \\
90(64-126) \\
0.2(0.1-0.4) \\
4.8(3.4-6.6)\end{array}$ & $\begin{array}{c}98(50-138) \\
0.49(0 \cdot 30-0.82) \\
0.68(0 \cdot 20-1 \cdot 20) \\
889(613-1,327) \\
91(75-124) \\
0.2(0.1-0.4) \\
3.3(1.8-4 \cdot 7)\end{array}$ \\
\hline
\end{tabular}

${ }^{*} 1 \mu \mathrm{g} / \mathrm{dl}$ for lead, mercury, cadmium, zinc, copper, manganese, and chromium correspond to $0.048,0.050,0.089,0.15,0.16,0.18$, and $0 \cdot 19 \mu \mathrm{mol} / \mathrm{l}$, respectively.

+ Blood lead concentration ranged from 22 to 59 (mean 38) $\mu \mathrm{g} / \mathrm{dl}$. $\ddagger$ Represents total (inorganic and organic) mercury (the plasma and erythrocyte concentrations of inorganic mercury were 0.23 $(0.12-0.38) \mu \mathrm{g} / \mathrm{dl}$ and $0.29(0.15-0.42) \mu \mathrm{g} / \mathrm{dl}$, respectively).

\section{Subjects and methods}

\section{SUBJECTS}

The 20 subjects, aged 34 to 59 (mean 49), were male gun metal foundry workers employed at a metal factory for 2-17 (mean 10) years. Their $\mathrm{BPb}$ and plasma and erythrocyte concentrations of lead, mercury (total mercury), cadmium, zinc, copper, manganese, $\bar{c}$ and chromium (PPb, EPb, PHg, EHg, PCd, ECd, PZn, EZn, PCu, ECu, PMn, EMn, PCr, and ECr) are shown in the table. The $\mathrm{BPb}, \mathrm{PZn}$, and $\mathrm{PCu}$ concen-? trations in these workers were significantly higher $\vec{F}$ than those in 16 male steel foundry workers at the same factory, 8-20 (mean 13) $\mu \mathrm{g} / \mathrm{dl}(0.4-1.0$ (mean $0.6) \mu \mathrm{mol} / \mathrm{l})$ for $\mathrm{BPb}, 54-97$ (mean 72) $\mu \mathrm{g} / \mathrm{dl}\left(8 \cdot 3-14.8 \frac{\bar{\sigma}}{\bar{\omega}}\right.$ (mean 11.0) $\mu \mathrm{mol} / \mathrm{l})$ for PZn, and 50-100 (mean 73) $\mu \mathrm{g} / \mathrm{dl} \quad(7.9-15.7$ (mean 11.5) $\mu \mathrm{mol} / \mathrm{l}$ ) for $\mathrm{PCu}, \varrho$ respectively $(p<0.05)$. No subject had ever suffered के from renal disease; neither albuminuria nor glu- $\vec{O}$

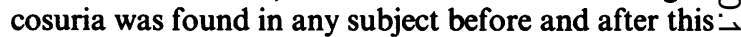
study.

\section{COLLECTION AND ANALYSIS OF BLOOD} AND URINE SAMPLES

Following collection of urine samples for 24 hours $\stackrel{\vec{\omega}}{\omega}$ in 20 subjects, blood samples were collected; then CaEDTA was administered by intravenous infusion $\mathrm{C}^{\circ}$ for one hour into the subjects in a dosage of $20 \mathrm{mg}$ 。 $(53.4 \mu \mathrm{mol})$ per $\mathrm{kg}$ body weight in $250 \mathrm{ml}$ of $5 \%$ glu- - . cose solution; and 24 hour urinary excretion of lead, $\vec{c}$ mercury, cadmium, zinc, copper, manganese, and $\mathbb{D}$ chromium before and after CaEDTA administration $\underset{\mathbb{D}}{\stackrel{D}{*}}$
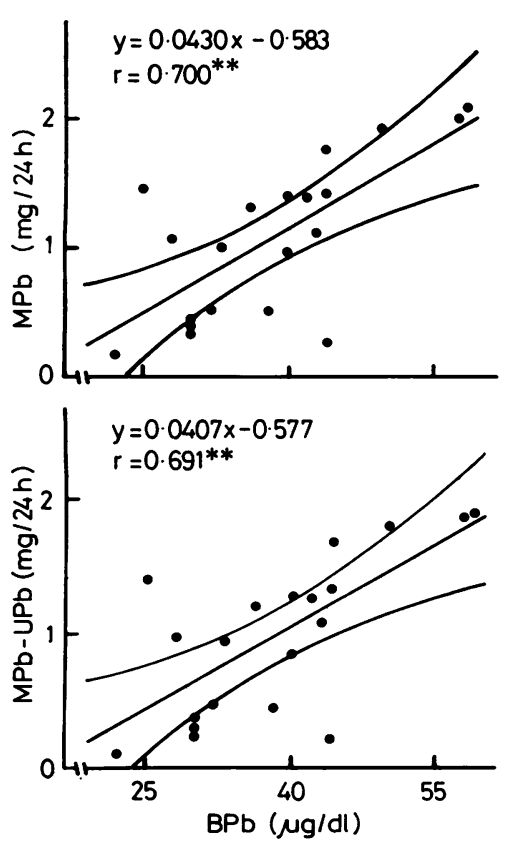
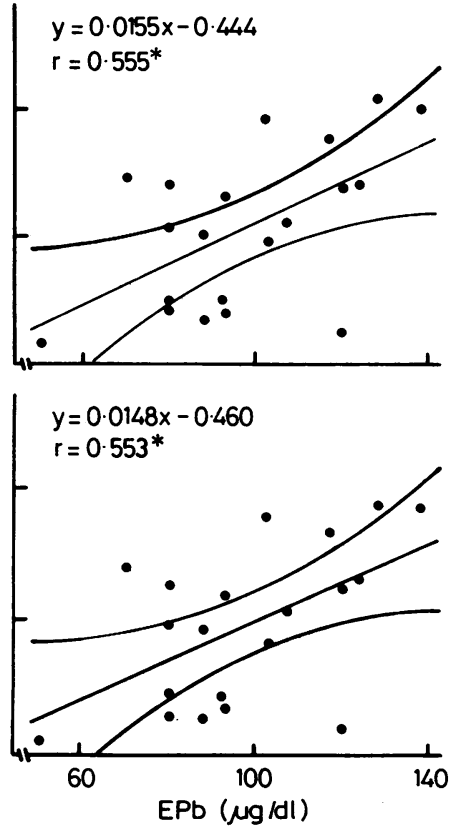
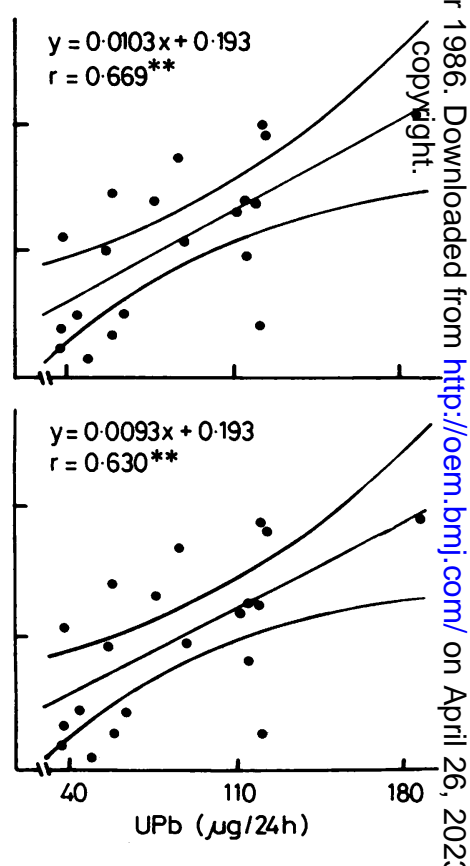

Fig 2 Correlations of mobilisation yield of lead in urine by $C a E D T A(M P b)$ and $M P b$ minus spontaneous urinary excretion of lead (UPb) with its whole blood and erythrocyte concentrations (BPb and EPb) and UPb in 20 subjects. ${ }^{*}$ and ${ }^{* *}$ indicate significant correlations at levels of $p<0.05$ and 0.01 , respectively (large sample conservative multiple significance test). Regression lines with $95 \%$ confidence limits are additionally shown. Conversion to SI units as in table and fig 1 . 

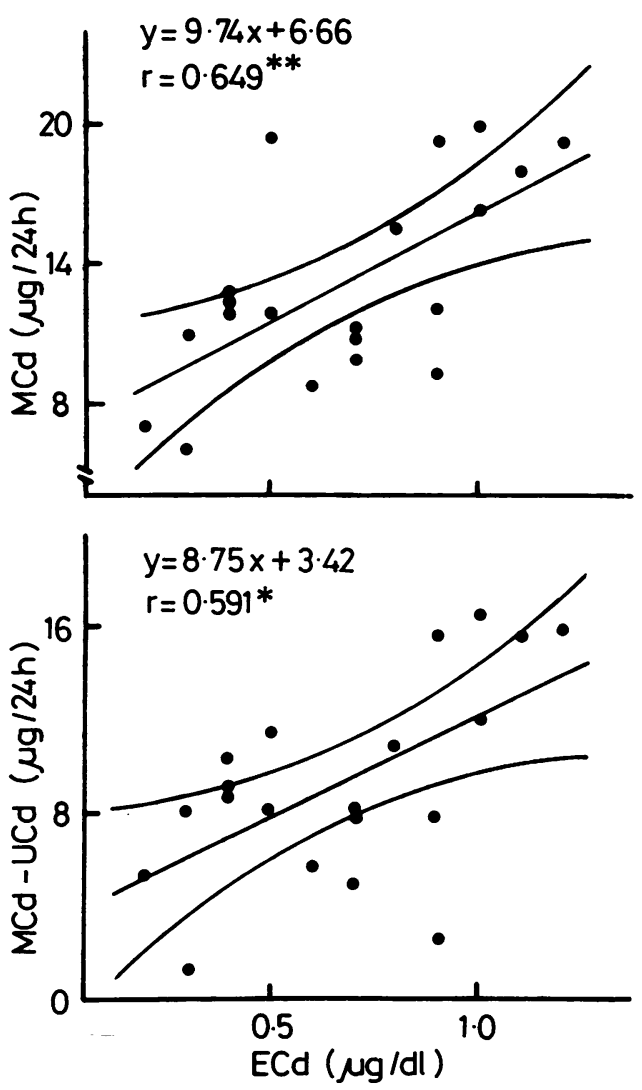

Fig 3 Correlations of mobilisation yield of cadmium in urine by $C a E D T A(M C d)$ and $M C d$ minus spontaneous urinary excretion of cadmium (UCd) with its erythrocyte concentration (ECd) in 20 subjects. ${ }^{*}$ and ${ }^{* *}$ indicate significant correlations at levels of $p<0.05$ and 0.01 , respectively (large sample conservative multiple significance test). Regression lines with $95 \%$ confidence limits are additionally shown. Conversion to SI units as in table and fig 1 .

(UPb, MPb, UHg, MHg, UCd, MCd, UZn, MZn, $\mathrm{UCu}, \mathrm{MCu}, \mathrm{UMn}, \mathrm{MMn}, \mathrm{UCr}$, and $\mathrm{MCr}$ ) was measured. The administration of CaEDTA was requested by the management and the workers at the factory. We explained to them that there was no medical indication for giving the chelating agent to them except for diagnostic purposes, and there is no evidence that in diagnostic and therapeutic doses this drug is hazardous to persons with "normal" renal function. ${ }^{9}$ They all elected to accept this test.

$\mathrm{BPb}, \mathrm{EPb}, \mathrm{UPb}$, and $\mathrm{MPb}$ concentrations were measured by atomic absorption spectrophotometry (AAS) (Hitachi polarised zeeman atomic absorption spectrophotometer 180-80) after wet ashing, chelation by sodium diethyldithiocarbamate (DDTC), and extraction into water saturated methylisobutyl ketone (MIBK); the PPb concentration was measured by the method of DeSilva. ${ }^{10}$ The total and inorganic mercury concentrations in plasma, erythrocytes, and urine were determined by the method of Magos (Sugiyama-gen mercury vapor meter MV-253R). ${ }^{11}{ }^{12}$ PCd, ECd, PCu, and ECu concentrations were measured by the flameless AAS after deproteinisation by trichloroacetic acid (TCA); UCd and MCd by the method of Subramanian et al. ${ }^{13}$ PZn, UZn, and MZn concentrations were measured by the AAS after deproteinisation by TCA; EZn by the AAS after wet ashing. PMn, EMn, PCr, and ECr concentrations were measured by the flameless AAS using the standard addition technique after deproteinisation by TCA; UCu, MCu, UMn, MMn, $\mathrm{UCr}$, and $\mathrm{MCr}$ concentrations by the AAS after wet ashing, chelation by DDTC, and extraction to MIBK. Urinary $\delta$-aminolaevulinic acid (ALA) and coproporphyrin (CP) were measured by the methods of Tomokuni and Ogata ${ }^{14}$ and Soulsby and Smith, ${ }^{15}$ respectively; and the activity of the intra-erythrocytic enzyme ALA dehydratase (ALAD) was determined by the European standardised method. ${ }^{16}$

The lower limits of detection were $0 \cdot 2,0.05,0 \cdot 2$, and $0 \cdot 1 \mu \mathrm{g} / \mathrm{dl}$ for $\mathrm{BPb}, \mathrm{PPb}, \mathrm{EPb}$, and $\mathrm{UPb}(\mathrm{MPb})$ concentrations, respectively; $0.05 \mu \mathrm{g} / \mathrm{dl}(0.002 \mu \mathrm{mol} / \mathrm{l})$ for $\mathrm{PHg}, \mathrm{EHg}$, and $\mathrm{UHg}(\mathrm{MHg}) ; 0.01 \mu \mathrm{g} / \mathrm{dl}(0.0009$ $\mu \mathrm{mol} / \mathrm{l})$ for PCd and ECd, and $0.05 \mu \mathrm{g} / \mathrm{dl}$ for UCd (MCd); $2 \mu \mathrm{g} / \mathrm{dl}$ for PZn, EZn, and UZn (MZn); $2 \cdot 5$ $\mu \mathrm{g} / \mathrm{dl}$ for $\mathrm{PCu}$ and $\mathrm{ECu}$, and $0.2 \mu \mathrm{g} / \mathrm{dl}$ for $\mathrm{UCu}$ $(\mathrm{MCu}) ; 0.1 \mu \mathrm{g} / \mathrm{dl}(0.02 \mu \mathrm{mol} / \mathrm{l})$ for PMn, EMn, and UMn (MMn); $0.2 \mu \mathrm{g} / \mathrm{dl}(0.04 \mu \mathrm{mol} / \mathrm{l})$ for $\mathrm{PCr}$ and $\mathrm{ECr}$, and $0.1 \mu \mathrm{g} / \mathrm{dl}$ for $\mathrm{UCr}(\mathrm{MCr})$; and $0.5 \mathrm{mg} / \mathrm{l}$ $(4 \mu \mathrm{mol} / \mathrm{l})$ and $5 \mu \mathrm{g} / 1(0.008 \mu \mathrm{mol} / \mathrm{l})$ for urinary ALA and $\mathrm{CP}$, respectively.

The reproducibility of analysis for blood, plasma, erythrocyte or urinary lead, zinc, copper, ALA, and $\mathrm{CP}$ has been reported previously (the coefficients of variation for determination of $\mathbf{B P b}, \mathbf{P P b}, \mathbf{E P b}$, and UPb were $3 \cdot 3,3 \cdot 5,3 \cdot 5$, and $3 \cdot 4 \%$, respectively). ${ }^{71}$ ? The coefficients of variation for determinations of other substances were $6.6 \%$ for $\mathrm{PHg}$ and $\mathrm{EHg}$, and $7 \cdot 1 \%$ for $\mathrm{UHg}(\mathrm{MHg}) ; 3.4 \%$ for PCd and ECd, and $4.8 \%$ for UCd (MCd); $6.4 \%$ for PMn and EMn, and $6.8 \%$ for UMn (MMn); and $4.1 \%$ for PCr and $\mathrm{ECr}$, and $5.8 \%$ for $\mathrm{UCr}(\mathrm{MCr})$.

\section{STATISTICAL ANALYSIS}

The difference between the spontaneous urinary excretion of heavy metal and its mobilisation yield in urine by CaEDTA was compared with paired sample $t$ tests. Correlations of $\mathrm{MPb}$ (and $\mathrm{MPb}$ minus UPb) with $\mathrm{BPb}, \mathrm{PPb}, \mathrm{EPb}$, and $\mathrm{UPb}$ and with $\mathrm{ALA}, \mathrm{CP}$, 

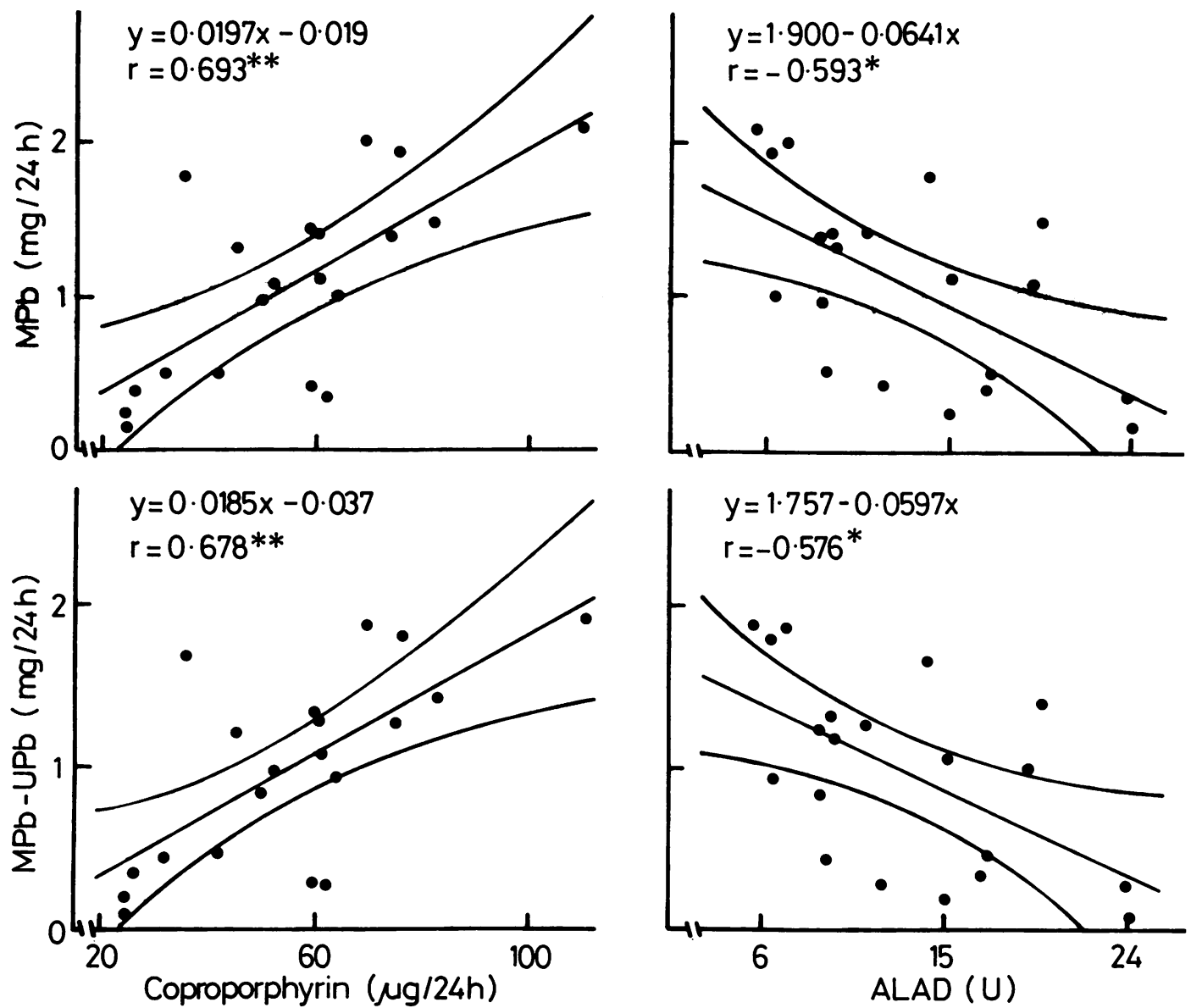

Fig 4 Correlations of mobilisation yield of lead in urine by $\mathrm{CaEDTA}(\mathrm{MPb})$ and MPb minus spontaneous urinary excretion of lead $(\mathrm{UPb})$ with urinary excretion of coproporphyrin and intra-erythrocytic enzyme $\delta$-aminolaevulinic acid dehydratase (ALAD) activity in 20 subjects. * and ** indicate significant correlations at levels of $p<0.05$ and 0.01 , respectively (large sample conservative multiple significance test). Regression lines with $95 \%$ confidence limits are additionally shown. $1 \mu \mathrm{g} / 24 \mathrm{~h}$ for coproporphyrin corresponds to $1.5 \mathrm{nmol} / 24 \mathrm{~h}$.

ALAD, and duration of lead exposure were analysed by a large sample conservative multiple significance test $^{18}$; multiple correlations for other metals were also analysed by this test.

\section{Results}

The urinary excretion of all metals, with the exception of mercury, significantly exceeded the pretreatment urinary excretion values (fig 1 ). $\mathrm{MPb}$ and the value for $\mathrm{MPb}$ minus $\mathrm{UPb}$ were significantly correlated with the $\mathrm{BPb}$ and $\mathrm{EPb}$ concentrations and $\mathrm{UPb}$ excretion (fig 2) but not with the PPb concentration $(r=0.28$ and 0.28 , respectively, $p>0.05)$ MCd and the value for MCd minus UCd were also significantly correlated with the ECd concentration (fig 3) but not with the PCd concentration $(r=0.14$ and 0.01 , respectively) and UCd excretion $(r=0.21$ and $-0.13)(\mathrm{p}>0.05)$. Furthermore, $\mathrm{MPb}$ and the value for $\mathrm{MPb}$ minus $\mathrm{UPb}$ were significantly correlated with urinary CP excretion and ALAD activity (fig 4). No significant correlation was found between the mobilisation yield of any two heavy metals.

\section{Discussion}

The 24 hour urinary excretion after CaEDTA infusion was on average 13 times the spontaneous excretion for lead, 11 times for zinc, 3.8 times for manganese, 3.4 times for cadmium, 1.3 times for copper, and 1.1 times for chromium; no significant increase was found for mercury. Our previous studies have shown that the ratio of $\mathrm{MPb}$ to $\mathrm{UPb}$ was on 
average 4.8 for non-exposed "healthy" men and 9.8 for lead workers (their UPb averaged 20 and 61 $\mu \mathrm{g} / 24 \mathrm{hr}$, respectively). ${ }^{219}$ In this study the $\mathrm{UPb}$ averaged $85 \mu \mathrm{g} / 24 \mathrm{hr}$. It is thus suggested that the higher the pretreatment $\mathrm{UPb}$ the higher the rise in $\mathrm{MPb}$ and $\mathrm{MPb}$ minus $\mathrm{UPb}$. The same evidence has been given for the relation between $\mathrm{BPb}$ and $\mathrm{MPb}$ in lead workers by $u^{26}$ and in children by Chisolm et al. ${ }^{20}$

In 1959 Perry and Perry injected $3 \mathrm{~g}$ CaEDTA intravenously into six patients with hypercholesterolaemia, and found a pronounced increase in 24 hour urinary zinc excretion (the ratio of $M Z n$ to $U Z n$ $(\mu \mathrm{g} / \mathrm{l})$ was 11) and lesser but consistent increases in lead, cadmium, and manganese excretion. ${ }^{21}$ In 1958 Teisinger and Fiserová-Bergerová found that $2.8 \mathrm{~g}$ CaEDTA increased the urinary secretion of copper from $0-124 \mu \mathrm{g} / 24 \mathrm{hr}$ to $62-249 \mu \mathrm{g} / 24 \mathrm{hr}^{22}$ In 1955 Bell $e t$ al did not find an increase in urinary mercury excretion by CaEDTA in a patient of chronic mercury poisoning ${ }^{23}$ whereas Woodcock did. ${ }^{24}$ Our present and past ${ }^{19}$ results do not differ substantially from those observations; furthermore, the present study indicated a slight but significant increase in chromium excretion and a non-significant increase in mercury excretion in men free from occupational exposure to these metals.

$\mathrm{MPb}$, together with the value for $\mathrm{MPb}$ minus $\mathrm{UPb}$, was significantly correlated with CP and ALAD. This confirms previous findings ${ }^{25}$ and indicates that $\mathrm{MPb}$ reflects the body burden of chelatable lead on which toxicity depends. Similarly, the high correlations of $\mathrm{BPb}, \mathrm{EPb}$, and $\mathrm{UPb}$ with $\mathrm{MPb}$ and $\mathrm{MPb}$ minus $\mathrm{UPb}$ indicate that $\mathrm{BPb}, \mathrm{EPb}$, and $\mathrm{UPb}$, but not $\mathrm{PPb}$, closely reflect the body burden of chelatable lead; the correlations of ECd with MCd and MCd minus UCd suggest that ECd, but not PCd and UCd, directly reflects the body burden of chelatable cadmium.

On the other hand, MZn did not correlate with either PZn or EZn ( $\mathrm{r}=\mathbf{0 . 3 1}$ and $\mathbf{0 . 2 2}$, respectively, $p>0.05$ ). Similarly, no significant correlation was found between $\mathrm{MCu}$ and $\mathrm{PCu}$ or $\mathrm{ECu}$, between $\mathrm{MMn}$ and PMn or EMn and between $\mathrm{MCr}$ and $\mathrm{PCr}$ or ECr. These findings suggest that zinc, copper, manganese, and chromium are mainly mobilised from organs other than the peripheral blood.

We thank Professor PJ Landrigan, Mount Sinai School of Medicine, for his valuable comments and Miss S Yasumi, Medical College of Oita, for her help in preparing the manuscript.

\section{References}

1 Araki S, Aono H, Fukahori M, Tabuki K. Behavior of lead and zinc in plasma, erythrocytes, and urine and ALAD in erythrocytes following intravenous infusion of CaEDTA in lead workers. Arch Environ Health 1984;39:363-7.

2 Araki S. Evaluation of lead mobilization test with intravenous infusion of CaEDTA in workers occupationally exposed to lead. Ind Health (Japan) 1975;13:179-89.
3 Alessio L, Castoldi MR, Monelli O, Toffoletto F, Zocchetti C. Indicators of internal dose in current and past exposure to lead. Int Arch Occup Environ Health 1979;44:127-32.

4 Brangstrup-Hansen JP, Døssing M, Paulev P-E. Chelatable lead body burden (by calcium-disodium EDTA) and blood lead concentration in man. $J$ Occup Med 1981;23:39-43.

5 Alessio L, Castoldi MR, Odone P, Franchini I. Behaviour of indicators of exposure and effect after cessation of occupational exposure to lead. Br J Ind Med 1981;38:262-7.

6 Araki S, Ushio K. Assessment of the body burden of chelatable lead: a model and its application to lead workers. Br J Ind Med 1982;39:157-60.

7 Aono H, Araki S. The effects of CaEDTA injection on lead, zinc, copper and ALAD in erythrocyte, plasma and urine in leadexposed workers: a 24-h observation. Int Arch Occup Environ Health 1984;55:13-8.

8 Aono $\mathrm{H}$, Araki S. The body burden of chelatable lead, zinc and copper: a kinetic study in lead workers. Jpn J Hyg 1985;40:340. (In Japanese).

9 Araki S, Murata K, Aono H, Yanagihara S, Ushio K. A comparison of the diminution rates of lead in blood and lead mobilized by CaEDTA after termination of occupational exposure: a long-term observation in two lead workers. $J$ Toxicol Clin Toxicol 1983;20:475-86.

10 DeSilva PE. Determination of lead in plasma and studies on its relationship to lead in erythrocytes. Br J Ind Med 1981;38: 209-17.

11 Magos L. Selective atomic-absorption determination of inorganic mercury and methylmercury in undigested biological samples. Analyst 1971;96:847-53.

12 Magos L, Clarkson TW. Atomic absorption determination of total, inorganic, and organic mercury in blood. $J$ Assoc Off Anal Chem 1972;55:966-71.

13 Subramanian KS, Meranger J-C, MacKeen JE. Graphite furnace atomic absorption spectrometry with matrix modification for determination of cadmium and lead in human urine. Anal Chem 1983;55:1064-7.

14 Tomokuni K, Ogata M. Simple method for determination of urinary $\delta$-aminolevulinic acid as an index of lead exposure. Clin Chem 1972;18:1534-6.

15 Soulsby J, Smith RL. A simplified method for the quantitative determination of urinary coproporphyrin in lead workers. $\mathrm{Br} J$ Ind Med 1974;31:72-4.

16 Berlin A. European standardized method for the determination of delta-aminolevulinic acid dehydratase activity in blood. Zeitschrift für Klinische Chemie und Klinische Biochemie 1974;12:389-90.

17 Araki S, Murata K, Yokoyama K, et al. Circadian rhythms in the urinary excretion of metals and organic substances in "healthy" men. Arch Environ Health 1983;38:360-6.

18 Morrison DF. Multivariate statistical methods. New York: McGraw-Hill, 1976:116-20.

19 Araki S. On the behaviour of "active deposit of lead (Teisinger)" in the Japanese free from occupational exposure to lead. Ind Health (Japan) 1973;11:203-24.

20 Chisolm JJ Jr, Mellits ED, Barrett MB. Interrelationships among blood lead concentration, quantitative daily ALA-U and urinary lead output following calcium EDTA. In: Nordberg GF, ed. Effects and dose-response relationships of toxic metals. Amsterdam: Elsevier, 1976:416-33.

21 Perry HM, Perry EF. Normal concentrations of some trace metals in human urine: changes produced by ethylenediaminetetraacetate. $J$ Clin Invest 1959;38:1452-63.

22 Teisinger J, Fišerová-Bergerová V. Über den Einfluß des zur Therapie der Bleivergiftung angewendeten Calciumdinatriumsalzes der Äthylendiamintetraessigsäure auf den Eisen- und Kupferspiegel im Blut und Urin. Archiv für Gewerbepathologie und Gewerbehygiene 1958;16:478-89.

23 Bell RF, Gilliland JC, Dunn WS. Urinary mercury and lead excretion in a case of mercurialism. Arch Ind Health 1955;11:231-3.

24 Woodcock SM. A case illustrating the effect of calcium disodium versenate (CaNa2EDTA) on chronic mercury poisoning. $\mathrm{Br} J$ Ind Med 1958;15:207-8. 